\title{
Waste water reuse pathways for processing tomato
}

Battilani, A.; Plauborg, Finn; Andersen, M.N.; Andersen, M.; Schweitzer, A.; Steiner, M.; Sandei, L.; Gola, S; Dalsgaard, Anders; Forslund, Anita; Klopmann, W.; Solimando, D.

\section{Published in:}

Acta Horticulturae

Publication date:

2009

Document version

Publisher's PDF, also known as Version of record

Citation for published version (APA):

Battilani, A., Plauborg, F., Andersen, M. N., Andersen, M., Schweitzer, A., Steiner, M., Sandei, L., Gola, S., Dalsgaard, A., Forslund, A., Klopmann, W., \& Solimando, D. (2009). Waste water reuse pathways for processing tomato. Acta Horticulturae, (823), 61-68. http://www.actahort.org.ep.fjernadgang.kb.dk/books/823/823_5.htm 


\title{
Waste Water Reuse Pathways for Processing Tomato
}

\author{
A. Battilani ${ }^{1}$, F. Plauborg ${ }^{2}$, M.N. Andersen ${ }^{2}$, M. Andersen ${ }^{3}$, A. Schweitzer ${ }^{4}$, M. Steiner ${ }^{5}$, \\ L. Sandei ${ }^{6}$, S. Gola ${ }^{6}$, A. Dalsgaard ${ }^{7}$, A. Forslund ${ }^{7}$, W. Klopmann ${ }^{8}$ and D. Solimando ${ }^{1}$ \\ ${ }^{1}$ Consorzio di Bonifica di Secondo Grado per il Canale Emiliano Romagnolo, Italy \\ ${ }^{2}$ University of Aarhus, Faculty of Agricultural Sciences, Dept. of Agroecology and \\ Environment, Denmark \\ ${ }^{3}$ Grundfos Biobooster A/S, Denmark \\ ${ }^{4}$ Netafim, Israel \\ ${ }^{5}$ Swiss Federal Institute of Environmental Science and Technology, Switzerland \\ ${ }^{6}$ Stazione Sperimentale per l'Industria delle Conserve Alimentari, Italy \\ ${ }^{7}$ University of Copenhagen, Dept. Life Science, Denmark \\ ${ }^{8}$ Bureau de Researches Geologique et Minieres, France
}

Keywords: faecal contamination, heavy metals, water treatment, nutrient recovery

\begin{abstract}
Direct or indirect water reuse involves several aspects: contamination by faecal, inorganic and xenobiotic pollutants; high levels of suspended solids and salinity; rational use of the dissolved nutrients (particularly nitrogen). The challenge is to apply new strategies and technologies which allow for use of the lowest irrigation water quality without harming food safety, yield and fruit or derivatives of quality. The EU project SAFIR aims to help farmers solve problems with low quality water and decreased access to water. New water treatment devices (prototypes) are under development to allow a safe use of waste water produced by small communities/industries $(\leq \mathbf{2 0 0 0}$ EI) or of treated water discharged into irrigation channels. Water treatment technologies are coupled with irrigation strategies and technologies to obtain flexible, easy to use, integrated management.
\end{abstract}

\section{INTRODUCTION}

The thought that water resources are capable of diluting whatever amount of pollutants is no longer acceptable, even for areas rich in water and with high rainfall. On the contrary, water resources are in an evident general state of degradation and are becoming increasingly scarce: during the past decade severe drought seasons have affected not only Mediterranean regions, but the most productive areas as well. Meanwhile, under the pressure of market globalisation, the processing tomato is evolving ever more as a water-demanding crop with most of the world processing tomato acreage located in areas prone to drought. Therefore, intensive farming must face its responsibilities for the conservation of water. A global water shortage is looming and it will become inevitable that agriculture surrender its priority position to human use through re-utilising urban effluents.

Is the need for adaptation really bad news, or can it be turned into an opportunity? There is no easy answer. The array of opportunities varies considerably and it is clear that adaptation will require politically painful choices, investments and time. However, in a world water crisis scenario, stubbornly considering properly treated wastewater as a waste to dispose of instead of as a resource will no longer be sustainable, neither in terms of social costs nor from an ecological standpoint. Urban effluents can be treated by screening out pollutants that are incompatible with irrigation use. This reclaimed wastewater may be used for crop irrigation without undue restrictions, provided the bacteriological quality is acceptable and the supplied volume does not exceed the water requirement maximising crop water use efficiency.

Sustainability of cropping systems, along with food safety and quality are a worldwide concern. The processing tomato is an important crop for Mediterranean countries and tomato derivatives are an important part of the human diet. Furthermore, processing tomato by-products are the main source of many phytochemicals, like 
lycopene, along with vitamin E, etc., which are widely used in cosmetics and health care products.

As a consequence, primary food industries and retailer organisations are developing an increasing awareness that "safe foods are produced in safe environments", which includes sustainable water supplies, from certified, good quality water sources. For all the western countries there is currently a strong focus on food quality and safety among consumers, the scientific community and other stakeholder organisations, which is also reflected in the recent formation of food production standards (GlobalGAP, 2007). This has, however, added a factor of stress and revealed a vulnerable element in the processing tomato production chain: its increasing dependence on good quality water resources. Tomato commodities have a high content of virtual water, which represents a withdrawal from the water footprint of the producer countries and a net water income for the importer. In view of the need for Mediterranean countries to reduce their water footprint according to the resources increasing scarcity, the European Commission is placing pressure on agriculture to reduce its use of irrigation water. In this scenario the cost of the virtual water exported could affect the tomato derivative price. As a consequence water scarcity could very well soon affect the ability of European tomato growers to compete on world market levels.

The EU project SAFIR aims to help processing tomato growers solve problems with low quality water and decreased access to water. Polluted surface and groundwater, as well as treated urban and industrial effluents, may be transformed into new, nonconventional, water resources by new water treatment devices (prototypes). A membrane bioreactor (MBR, Grundfos BioBooster A/S, patent pending) and a modular field treatment system (FTS) are under development to allow safe use of waste water produced by small communities/industries $(\leq 2000 \mathrm{EI})$ or of traditional water sources now polluted by anthropic activities. Water treatment technologies are coupled with irrigation strategies and technologies to obtain a flexible, easy to use, integrated irrigation management. The SAFIR irrigation management may fulfil Disability Adjusted Life Year (DALYs) risk analysis criteria, as requested by the new WHO standards (2006), as well as GlobalGAP standards.

\section{STUDY}

\section{From Wastes to Resources}

The SAFIR project is based on a holistic perception of technological development which aims to significantly reduce risk of food quality and hygiene impairments, while poor quality water along with its nutrients content is reclaimed. The SAFIR integrated treatment flow chart is shown in Figure 1. The main water sources reclaimed were as follows:

1. Primary waste water (PWW) from small communities $(\leq 2000$ EI), industrial or residential areas.

2. Secondary treated waste water (not filtered, not disinfected) (SWW) produced by urban water treatment plant. Discharge of SWW into surface water, already polluted or not, the so-called indirect reuse, is a common practice. This is probably the most abundant and diffused water source in Mediterranean areas that needs to be treated on site, similarly to polluted groundwater.

3. Secondary waste water, already disinfected and screened for main pollutants, that may require further on site refinement to avoid food contamination.

SAFIR integrated water treatment consist of three stages. Treatment phase 1 provides water which is treated with MBR or FTS technology in function of its pollutant loads (Fig. 1). Properly treated SWW, although not filtered and disinfected, could be treated only with a simple gravel filter. Phase 2 provides a further refinement of water by means of a suitable irrigation method. Buried drip line (sub-surface drip irrigation, SDI) is considered the best option; however, drip irrigation, sprinkler and furrow were also tested and compared with SDI. Irrigation strategy (phase 3) is considered as a part of the 
integrated water treatment. Impact of both soil humidity and suspension of irrigation on faecal contamination of soil and fruits is well documented in literature. A decision support system drives irrigation management aimed to save water and allows soil humidity to be kept in the root zone at a suitable level for the plant, while avoiding optimal conditions for bacteria survival. Moreover, supplying strictly the amount of water needed to obtain good tomato yield and quality also keeps the pollutant accumulation in the receiving soil in a tolerable range. This is provided that the bioavailability of inorganic pollutants (e.g. arsenium or cadmium) is mainly a function of its concentration in the pore water, where reducing available water can therefore limit their uptake by plant roots.

\section{MBR Treatment Pathway}

The MBR prototype is aimed to offer a viable option to replace conventional wastewater treatment for small communities, scattered houses and factories. The prototype brings together membrane ultrafiltration technologies and enhanced activated sludge digestion, minimising the size of the treatment device and consuming the amount of energy comparable to a traditional water treatment process. In areas with high anthropogenic pressure and human footprint index, MBR treatment provide high quality, filtered and disinfected, water for irrigation. Water produced with MBR does not require further filtration and can be safely used with every irrigation method. The MBR prototype is designed without denitrification. To profit from the MBR water nitrate content, and to avoid accumulation in fruit or excessive vegetative growth, fertilisation and fertigation schedule were managed by a DSS (Fertirrigere V3.2).

\section{FTS Treatment Pathway}

On site FTS treatment was developed, adapted and implemented in an advanced filter station using urban and industrial waste water treatment technologies (Fig. 2). The FTS does not aim to replace conventional wastewater treatment systems, as with MBR, but merely the purpose is to allow safe use of poor quality water for irrigation purposes on a very small scale. The configuration of the FTS prototype is flexible and changeable according to the raw water quality and to the risk of pollutants and pathogens bioaccumulation/contamination in the horticultural products. Up to this point, available technologies have not allowed for economic removal of salt and/or nitrate at the field scale. For that reason FTS focuses on two major issues: faecal contamination and heavy metal pollution. The configuration of the prototype ranges from a simple gravel filter adapted and managed to enhance its capability to partially remove particulate bound to a complete set up that includes a special filter able to remove the most harmful heavy metals (arsenium, cadmium, chromium), as well as excess of lead and copper, and an UV disinfection lamp. FTS components could work separately, being bypassed when raw water does not require inorganic pollutant removal or disinfection. Only the gravel filter, which acts as the first barrier, can not be disconnected. As with the MBR pathway, management of nitrate accumulation which might occur in the fruits was achieved by using precise fertigation coupled with water saving irrigation strategies aimed to reduce bioaccumulation and biomagnification of pollutants along the food chain.

\section{MATERIAL AND METHODS}

To assess prototype effectiveness, the water outlet characteristics of each system were compared with tap water. Three water sources were used to irrigate field trials carried out in 2006 and 2007 in the Po Valley (Italy): tap water (TW), secondary waste water, not filtered or disinfected, treated only with a gravel filter (FTS) and primary waste water from a small water treatment plant $(<2000 \mathrm{EI})$ treated with MBR. Tomatoes were grown on a silty-clay soil (sand $24 \%$, silt $41 \%$, clay $35 \%$ ), with a bulk density of $1.234 \mathrm{t}$ $\mathrm{m}^{-3}$, a field capacity of $0.345 \mathrm{~m}^{3} \mathrm{~m}^{-3}$, and a wilting point of $0.214 \mathrm{~m}^{3} \mathrm{~m}^{-3}$. A shallow water table, present at $-0.8 \mathrm{~m}$ in springtime until early June, represented an important hydrological boundary condition limiting and slowing the downward movements of 
solutes and contaminants, while capillary rise significantly contributed to the upward movement as well as to the maintenance of a favourable environment for faecal contaminants. Experimental design was a split plot schema with 3 replications. Irrigation and fertigation schedule were managed applying a DSS (Fertirrigere V3.2) developed for processing tomato fertigation management, and validated in the area (Battilani, 2003). Tomatoes received 257.3 and $251 \mathrm{~mm}$ of irrigation water in 2006 and 2007 respectively. Rainfall during the cropping season was $48.3 \mathrm{~mm}$ in 2006 and $178.5 \mathrm{~mm}$ in 2007 . Water movements around the dripper were monitored by means of TDR measurements. The soil sampling schema was designed accordingly to the observed water distribution geometry. Plots were irrigated by sprinkler or with buried drip lines (SDI). Only SDI results are reported in this paper. Fruits were analysed at harvest for its heavy metal content and faecal contamination (E. coli). The main rivers and streams in the area, which represent the main source of irrigation water, were monitored by the Regional Environment Protection Agency (ARPA). Groundwater pumped from farm wells was also monitored. Average values were calculated from the large database and compared with the SAFIR's treated waters.

\section{RESULTS AND DISCUSSION}

Soils possess natural abilities to assimilate, attenuate and detoxify pollutants making it possible to obtain agronomic benefits when applying treated wastewater. Proper treatment and management allow for safe use of poor quality water avoiding accumulation of pollutants in soils or along the food chain, along with controlling their concentration to avoid reaching levels harmful to human health. The main concern, however, relates to faecal contamination of raw products and takes into consideration the water-soil-fruit, water-fruit, water-soil-plant-fruit (endophytic) contamination pathways. The results of the monitoring campaigns done in 2006 and 2007 show, as expected, a higher concentration of Escherichia coli in FTS water $\left(10^{2}\right.$ to $\left.10^{3}\right)$ compared with tap and MBR water. Distribution with SDI technology allows a reduction of the higher microbial load of 1 order of magnitude in the upper soil layer $(0-30 \mathrm{~cm})$ and of 2 orders of magnitude in the lower soil layer $(30-60 \mathrm{~cm})$. E. coli concentration on fruit was always below the detection limit (Table 1). Heavy metal bioaccumulation into the fruit and its magnification along the food chain is also a matter of concern. Several food safety alerts have been raised over the last several years relating to this issue. The content of the most risky elements and molecules for soil, plant and human health in the SAFIR treated water are compared with those of surface and ground water (Table 2). FTS and MBR irrigation water resulted in a higher content of sodium, chlorine sulphate and boron. Concentration of arsenium, cadmium, chromium, copper lead and zinc were similar for all water sources, with the exception of zinc, which was lower in the surface water. All measured concentrations were found to be below the allowable tolerance thresholds (Australian Gov., 2000; Canadian Council of Ministers of the Environment, 1999; South African Dept. of Water Affaires and Forestry, 1996; WHO, 2006). Table 3 reports the frequency of detection in fruit (concentration higher than the quantification limit) and the maximum concentration detected for the most harmful heavy metals and nitrate. Heavy metals, nitrate content and detection frequency were comparable among water sources. Tomatoes irrigated with FTS or MBR water were found to have the same heavy metal and nitrate content compared to those irrigated with tap water. Irrigation water also contains nutrients that are usually supplied as fertilisers where the NPK (nitrogen, phosphorus, potassium) supplied with surface water are not significant. Groundwater has a content of mineral nitrogen that could contribute to the plants requirements but phosphorus and potassium are negligible. FTS and MBR water contain significantly higher amount of nutrients that may benefit the crop when properly managed (Table 4). All the water sources were found to have a similar concentration of calcium and magnesium. A higher content of nutrients in irrigation water may profit growers up to $68 € \mathrm{ha}^{-1}$ when considering only NPK, and up to $€ 259 \mathrm{ha}^{-1}$ if part of the calcium and magnesium supplied with irrigation water is taken into account (Table 5). 


\section{CONCLUSIONS}

The SAFIR project will offer growers new and innovative technologies focused on the water quality needed to produce safe, high quality tomato derivatives. Applying the proposed treatment pathways allows both faecal and heavy metal contamination to be controlled, in turn avoiding accumulation of pollutants in soils or along the food chain. The safe reuse of treated waste water produced by a small plant (2000 EI) secures, independently of climate, enough irrigation water to support the production of 1100-1500 tonnes of tomatoes, when directly delivered to the field. A storage capacity corresponding to 7 days production would increase the tomato yield supported by the treatment plant to 1800-2400 tonnes, while a 30 days storage capability can support 2250-3000 tonnes yield. Moreover, at an irrigation rate of $2500 \mathrm{~m}^{-3} \mathrm{ha}^{-1}$ SAFIR treated water can supply up to 30 $\mathrm{kg} \mathrm{ha}^{-1}$ of nitrogen, reducing supplementary fertilisation needs with a consequent increase in farmers' income. To make water reuse a reality it is necessary to finally define the quality characteristics of irrigation water as different from that of treated wastewater for disposal or for surface water. The lack of clear regulation has led several international retail organisation and almost all the great chains of supermarkets to impose their own rules on the market. As a result, producers and consumers do not have a clear point of reference and remain in doubt about the acceptance of food produced with poor quality or reused water, leaving growers to simply use the higher quality water available and compete with urban uses. The need for a European, or even better, an International regulation is evident to ensure that a correct approach to improve the basin water balance is established while ensuring the ability to secure high food quality and safety.

\section{ACKNOWLEDGEMENTS}

The authors gratefully acknowledge the team of the EU project SAFIR. The research was funded by the EU-DG XII (contract PL023168 and the Emilia Romagna Region).

\section{Literature Cited}

Australian Gov. 2000. Australia and New Zealand guidelines for fresh and marine water quality. Volume 3 - Primary Industries, Water quality for irrigation and general use.

Battilani, A., Bussieres, P. and Dumas, Y. 2003. FERTIRRIGERE: A simple tool-model for managing water and nutrient supply in drip-irrigated processing tomatoes. Acta Hort. 613:155-158.

Battilani, A., Corticelli, A. and Zaccanti, M. 2003. Studio comparativo della qualità per usi irrigui delle principali fonti idriche emiliano-romagnole. Atti del seminario "Acquasave: riciclo e riutilizzo delle acque" Ecomondo ACQUA Rimini 22-24 ottobre, 362-370.

Caanadian Council of Ministers of the Environment. 1999. Canadian water quality guidelines. Protocols for Deriving Water Quality Guidelines for the Protection of Agricultural Water Uses (Irrigation and Livestock Water).

Chang, A.C., Pan, G., Page, A.L. and Asano, T. 2002. Developing human health-related chemical guidelines for reclaimed waster and sewage sludge application in agriculture. WHO edt Geneve $(\mathrm{CH})$.

GlobalGAP. 2007. The standard document- Fruit and vegetables. www.globalgap.org

South African Dept. of Water Affaires and Forestry, 1996. Water quality guidelines Volume 4 - Agricultural Use: Irrigation.

WHO. 2006. Guidelines for the safe use of wastewater, excreta and greywater. Volume 2 - Wastewater use in Agriculture. WHO edt Geneve (CH). 


\section{$\underline{\text { Tables }}$}

Table 1. SAFIR irrigation water sources measured Escherichia coli content (cfu/ml).

\begin{tabular}{|c|c|c|c|c|c|}
\hline & Average & Std Dev & Std Err & Min & Max \\
\hline \multicolumn{6}{|c|}{ Irrigation water } \\
\hline Tap water & 0.00 & 0.00 & 0.00 & 0.00 & 0.00 \\
\hline Field treated waste water & 232.65 & 684.03 & 88.31 & 0.00 & 3000.00 \\
\hline Membrane bioreactor & 4.32 & 5.14 & 0.74 & 0.00 & 20.00 \\
\hline \multicolumn{6}{|c|}{ Upper soil layer 0-30 cm } \\
\hline Tap water & 7.22 & 16.38 & 3.86 & 0.00 & 50.00 \\
\hline Field treated waste water & 34.44 & 141.22 & 33.28 & 0.00 & 600.00 \\
\hline Membrane bioreactor & 2.78 & 5.74 & 1.35 & 0.00 & 20.00 \\
\hline \multicolumn{6}{|c|}{ Lower soil layer 30-60 } \\
\hline Tap water & 0.00 & 0.00 & 0.00 & 0.00 & 0.00 \\
\hline Field treated waste water & 1.11 & 4.71 & 1.11 & 0.00 & 20.00 \\
\hline Membrane bioreactor & 0.67 & 2.58 & 0.67 & 0.00 & 10.00 \\
\hline \multicolumn{6}{|c|}{ Fruit } \\
\hline Tap water & $<\mathrm{LQ}$ & - & - & $<\mathrm{LQ}$ & $<\mathrm{LQ}$ \\
\hline Field treated waste water & $<\mathrm{LQ}$ & - & - & $<\mathrm{LQ}$ & $<\mathrm{LQ}$ \\
\hline Membrane bioreactor & $<\mathrm{LQ}$ & - & - & $<\mathrm{LQ}$ & $<\mathrm{LQ}$ \\
\hline
\end{tabular}

Table 2. Inorganic pollutants content in SAFIR water compared with surface and ground water in the area.

\begin{tabular}{lccccccccccccc}
\hline & \multicolumn{4}{c}{ Surface water } & \multicolumn{3}{c}{ Groundwater } & \multicolumn{3}{c}{ FTS - Safir } & \multicolumn{3}{c}{ MBR - Safir } \\
\hline & \multicolumn{3}{c}{ Avg } & \multicolumn{3}{c}{ Std Err. Avg } & \multicolumn{3}{c}{ Std Err. Avg } & \multicolumn{3}{l}{ Std Err. Avg } & \multicolumn{2}{c}{ Std Err. } \\
\hline $\mathrm{Na}$ & $\mathrm{mg} \mathrm{l}^{-1}$ & 24.00 & \pm & 1.20 & 20.92 & \pm & 1.29 & 66.11 & \pm 14.22 & 75.60 & \pm & 14.40 \\
$\mathrm{Cl}$ & $\mathrm{mg} \mathrm{l}^{-1}$ & 16.86 & \pm & 2.95 & 21.76 & \pm & 2.18 & 58.65 & \pm 17.04 & 84.85 & \pm & 10.15 \\
$\mathrm{SO}_{4}$ & $\mathrm{mg} \mathrm{l}^{-1}$ & 44.39 & \pm & 9.05 & 41.23 & \pm & 2.53 & 113.65 & \pm 17.76 & 56.20 & \pm & 6.20 \\
$\mathrm{~B}$ & $\mu \mathrm{g} \mathrm{l}^{-1}$ & 74.64 & \pm & 12.95 & 81.17 & \pm & 4.29 & 258.67 & \pm 66.83 & 201.20 & \pm & 44.31 \\
$\mathrm{As}$ & $\mu \mathrm{g} \mathrm{l}^{-1}$ & 10.00 & \pm & 0.50 & 2.19 & \pm & 0.31 & 2.57 & \pm & 0.36 & 4.92 & \pm & 1.92 \\
$\mathrm{Cd}$ & $\mu \mathrm{g} \mathrm{l}^{-1}$ & 0.21 & \pm & 0.15 & 0.25 & \pm & 0.00 & 0.26 & \pm & 0.11 & 0.91 & \pm & 0.49 \\
$\mathrm{Cr}$ & $\mu \mathrm{g} \mathrm{l}^{-1}$ & 1.46 & \pm & 0.25 & 3.32 & \pm & 0.22 & 3.40 & \pm & 1.09 & 4.10 & \pm & 1.35 \\
$\mathrm{Cu}$ & $\mu \mathrm{g} \mathrm{l}^{-1}$ & 4.91 & \pm & 1.54 & 7.14 & \pm & 1.37 & 13.33 & \pm & 3.34 & 14.40 & \pm & 7.02 \\
$\mathrm{~Pb}$ & $\mu \mathrm{g} \mathrm{l}^{-1}$ & 1.90 & \pm & 1.03 & 2.53 & \pm & 0.03 & 1.27 & \pm & 0.38 & 1.62 & \pm & 0.85 \\
$\mathrm{Zn}$ & $\mu \mathrm{g} \mathrm{l}^{-1}$ & 8.28 & \pm & 1.86 & 108.56 & \pm & 28.84 & 161.33 & \pm 53.71 & 114.90 & \pm & 60.36 \\
\hline
\end{tabular}


Table 3. Heavy metals and nitrate contamination of tomato fruits with different water sources .

\begin{tabular}{|c|c|c|c|c|c|c|}
\hline & \multicolumn{2}{|l|}{ Tap water } & \multicolumn{2}{|c|}{ FTS - Safir } & \multicolumn{2}{|c|}{ MBR - Safir } \\
\hline & $f \%$ & $\max \operatorname{mg~kg}{ }^{-1}$ & $f \%$ & $\max \mathrm{mg} \mathrm{kg}^{-1}$ & $\%$ & $\max \mathrm{mg} \mathrm{kg}^{-1}$ \\
\hline Arsenium & 8.33 & 0.05 & 8.33 & 0.03 & 8.33 & 0.05 \\
\hline Cadmium & 25.00 & 0.03 & 16.70 & 0.10 & 41.70 & 0.04 \\
\hline Cromium & 50.00 & 0.06 & 50.00 & 0.10 & 50.00 & 0.06 \\
\hline Copper & 91.70 & 1.07 & 100.00 & 1.11 & 100.00 & 1.15 \\
\hline Lead & 58.30 & 0.23 & 50.00 & 0.29 & 58.33 & 0.24 \\
\hline Zinc & 100.00 & 1.05 & 100.00 & 1.32 & 100.00 & 1.54 \\
\hline Nitrate & 75.00 & 8.10 & 66.70 & 9.63 & 75.00 & 8.97 \\
\hline
\end{tabular}

Table 4. Nutrients content in SAFIR water compared with surface and ground water in the area.

\begin{tabular}{lcrlllllllllllll}
\hline & \multicolumn{4}{c}{ Surface water } & \multicolumn{3}{c}{ Groundwater } & \multicolumn{3}{c}{ FTS - Safir } & \multicolumn{3}{c}{ MBR - Safir } \\
\hline & \multicolumn{3}{c}{ Avg } & \multicolumn{3}{c}{ Std Err. Avg } & \multicolumn{3}{c}{ Std Err. Avg } & \multicolumn{3}{c}{ Std Err. Avg } & \multicolumn{3}{c}{ Std Err. } \\
\hline $\mathrm{N}_{\text {MIN }}$ & $\mathrm{mg} \mathrm{l}^{-1}$ & 0.74 & \pm & 0.05 & 5.20 & \pm & 0.44 & 3.92 & \pm & 0.75 & 12.12 & \pm & 1.98 \\
$\mathrm{P}$ & $\mathrm{mg} \mathrm{l}^{-1}$ & 0.11 & \pm & 0.02 & 0.08 & \pm & 0.07 & 0.68 & \pm & 0.47 & 1.98 & \pm & 0.58 \\
$\mathrm{~K}$ & $\mathrm{mg} \mathrm{l}^{-1}$ & 2.70 & \pm & 1.00 & 1.94 & \pm & 0.14 & 8.20 & \pm & 2.13 & 8.70 & \pm & 1.82 \\
$\mathrm{Ca}$ & $\mathrm{mg} \mathrm{l}^{-1}$ & 82.93 & \pm & 6.61 & 103.98 & \pm & 2.84 & 86.60 & \pm 11.71 & 76.72 & \pm & 11.34 \\
$\mathrm{Mg}$ & $\mathrm{mg} \mathrm{l}^{-1}$ & 12.24 & \pm & 2.86 & 25.75 & \pm & 0.82 & 19.26 & \pm & 2.41 & 17.73 & \pm & 2.59 \\
\hline
\end{tabular}

Table 5. Cropping cost reduction related to the water nutrient contents.

\begin{tabular}{|c|c|c|c|c|c|c|c|}
\hline & $\mathrm{N}_{\text {MIN }}$ & $\mathrm{P}$ & $\bar{K}$ & $\mathrm{Ca}^{*}$ & $\mathrm{Mg}^{*}$ & Tot NPK & Tot \\
\hline & $€$ ha** $^{*}$ & $€$ ha** & $€$ ha** & $€$ ha** $^{*}$ & $€$ ha** & $€$ ha** & $€$ ha** $^{*}$ \\
\hline Surface water & 2.22 & 0.33 & 7.43 & 172.00 & 25.80 & 9.98 & 207.78 \\
\hline Groundwater & 15.60 & 0.24 & 5.34 & 172.00 & 25.80 & 21.18 & 218.98 \\
\hline FTS - Safir & 11.76 & 2.04 & 22.55 & 172.00 & 25.80 & 36.35 & 234.15 \\
\hline MBR - Safir & 38.16 & 5.94 & 23.93 & 164.95 & 25.80 & 68.03 & 258.77 \\
\hline
\end{tabular}




\section{Figures}

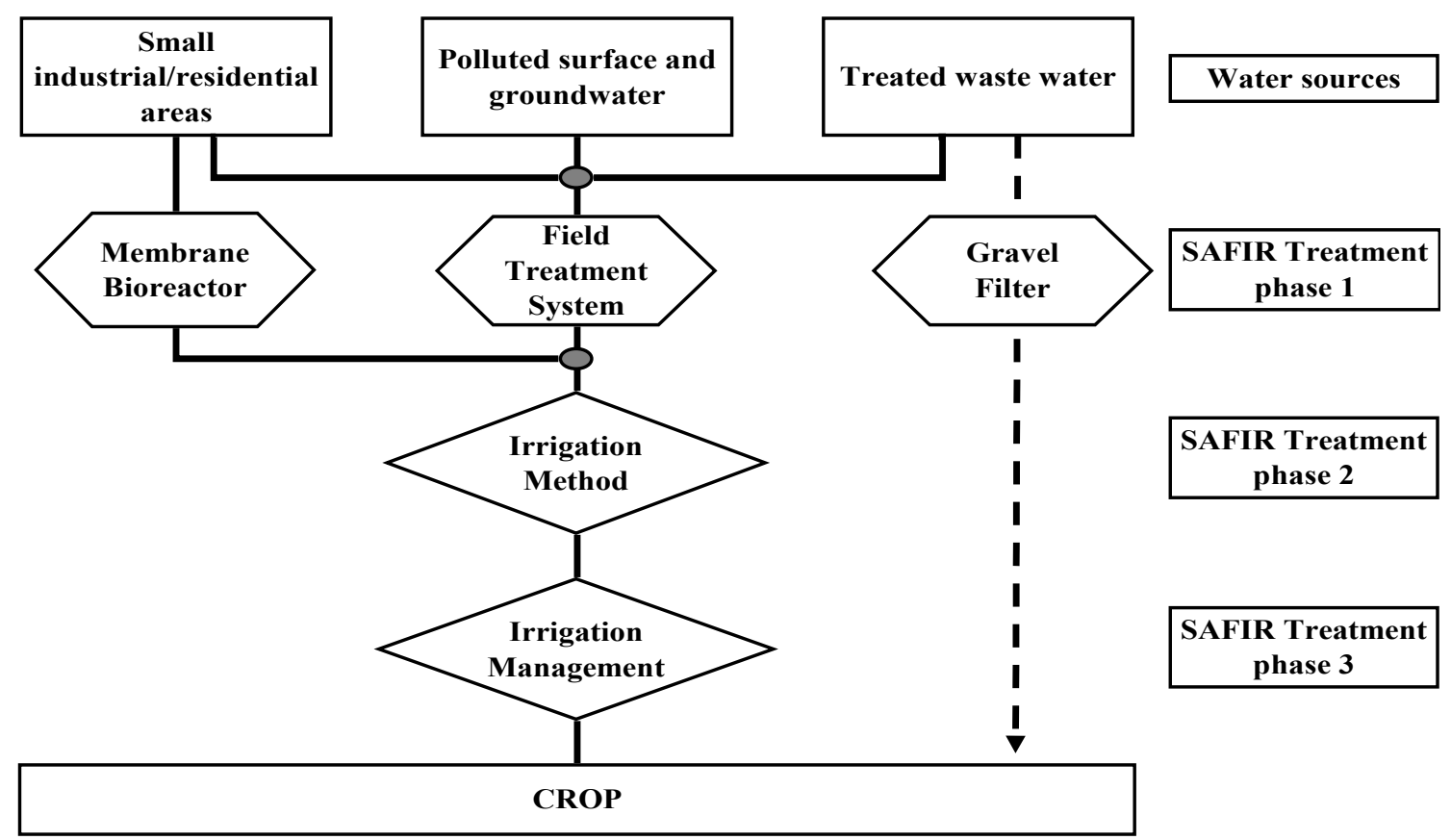

Fig. 1. Three stages SAFIR integrated water treatment schema.

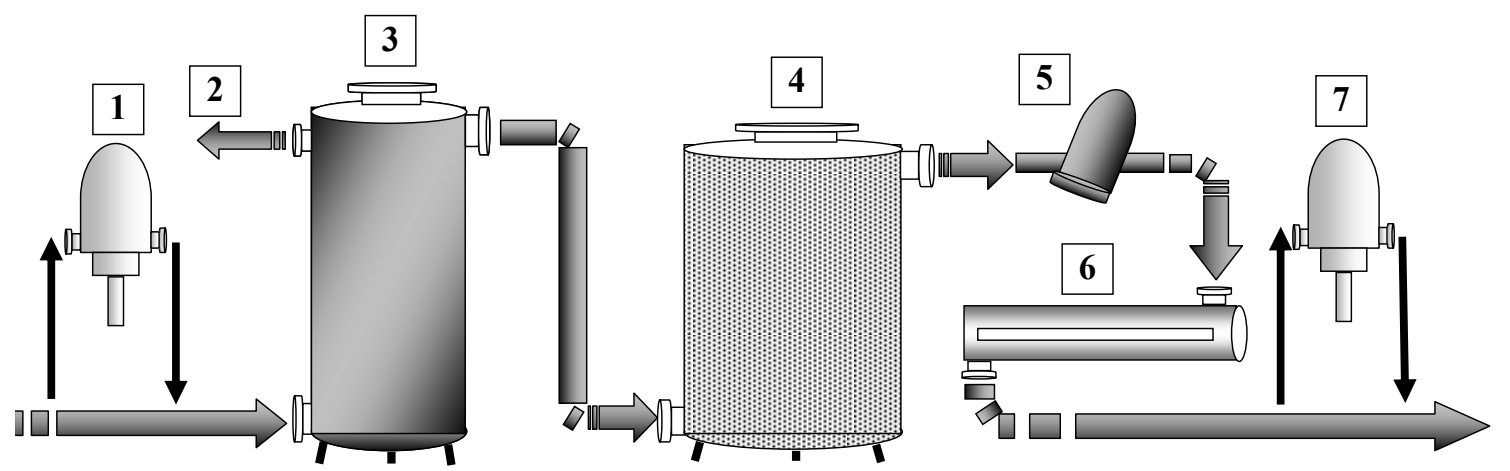

Fig. 2. Modular SAFIR field treatment system (FTS) with acidification pump (1), gravel filter $(2,3)$, heavy metal removal device (4), screen filter (5), UV lamp (6) and fertigation pump (7). 